\title{
MRI and Histological Features of Neurilemoma at Cauda Equina: A Case Report
}

\author{
Yadav AK ${ }^{1}$, Feng PY ${ }^{1}$, Chen XC ${ }^{1}$, Feng LJ ${ }^{2}$ \\ ${ }^{1}$ Department of Radiology, ${ }^{2}$ Department of Pathology, Shanghai $10^{\text {th }}$ People's Hospital of \\ Tongji University, Shanghai, China.
}

\begin{abstract}
We present a case of 61years old female, clinical manifestations of this entity, including left lumber continuous pain and discomfort with numbness at left gluteal region for 2 years. Pain had increase since one week with radicular pain in left leg. MRI study was performed with 3.0T unit (siemen) and revealed an oval shape mass behind the L3 vertebra, suggesting differential diagnosis of Neurilemoma or Ependymoma. The patient underwent surgical L3 laminectomy and total excision of the tumor. Pathological report confirmed diagnosis of Neurilemoma.
\end{abstract}

Keywords: MRI, Neurilemoma, Ependymoma, Laminectomy.

\section{Introduction}

Neurilemoma and Ependymoma both are different origin of spinal tumor and they are rare type of tumor. In 1910, first time Peripheral Nerve tumor was described by pathologist Verocay and in 1935 the term Nerurilemoma (NLM) was introduced by Scout in medical science. ${ }^{1}$ Neurilemoma make up less than $0.2-0.5 \%$ of the Neoplasm of the organism. Histological finding of Neurilemoma is the presence of A and B Antoni zones. ${ }^{2}$ S-100 protein present strongly in Neurilemoma. GFAP is weak in Neurilemoma.

Corrospondence to: Peng Yi Feng, Department of Radiology, Shanghai 10th people Hospital, Tongji University. Yanchangroad, Shanghai -200072.

Email:- peng2188@sina.com

\section{Case Report}

A right handed 61 years female presented to orthopedic out patient department with complaint of pain and discomfort at left lumber region with burning sensation at left gluteal region for 2 yrs. Pain had been increasing since last week and felt left leg pulling. No obvious muscle atrophy, weakness, or parathesia was noted. Gait, sleep pattern, bowel and bladder habit were normal. No exacerbating and alleviating factors, denied tobacco uses, occasionally consume alcohol. No any past history of trauma and medical disease. She had lithotripsy 1 year back. On physical examination SLRT > 60\%, sensory intact, motor intact, $\mathrm{B} / \mathrm{L}$ leg motor $5 / 5$ rated. No babinski sign, reflexes are normal except Deep tendon relflex was positive. 
Table 1: MRI signal of Neurilemoma

\begin{tabular}{|l|l|}
\hline & \multicolumn{1}{|c|}{ Neurilemoma } \\
\hline MRI signals & Sagital \\
\hline T1WI & Isointense \\
\hline T2WI & $\begin{array}{l}\text { Hyperintense in central } \\
\text { and hypointense in } \\
\text { periphery. }\end{array}$ \\
\hline T1, C+ & $\begin{array}{l}\text { Hyperintense in periphery } \\
\text { \& hypointensel in central. }\end{array}$ \\
\hline
\end{tabular}

Vitals were stable, Laboratory test findings were within normal limit. Plain $\mathrm{x}$-ray of lumber spine demonstrated normal. 3.0 T Unit (Siemens) Magnetic resonance images (MRI) with contrast Gd -DTPA $30 \mathrm{ml}$, SAG: T1WI / TSE, T2WI / TIRM, TRA: T2Wi/TSE showed oval shape mass in periphery with high signal and low signal in central of the mass. No dural tail sign was seen. Provisional diagnosis was made as Neurilemoma and Ependymoma.

Table 2: Histopathology of Neurilemoma.

\begin{tabular}{|l|l|}
\hline & Neurilemoma \\
\hline $\begin{array}{l}\text { Histological } \\
\text { pattern }\end{array}$ & $\begin{array}{l}\text { Spindles cells arranged in } \\
\text { intersecting bundles } \\
\text { (Atoni A) \& areas with } \\
\text { less cellularity with } \\
\text { loosely arranged cells } \\
\text { (Atoni B) }\end{array}$ \\
\hline $\begin{array}{l}\text { Cytological } \\
\text { features }\end{array}$ & $\begin{array}{l}\text { Long club shaped } \\
\text { Nuclei } \\
\text { Chromatin } \\
\text { Cytoplasm }\end{array}$ \\
\hline $\begin{array}{l}\text { Mitotic } \\
\text { Activity }\end{array}$ & $\begin{array}{l}\text { Present Rare } \\
\text { Necrosis }\end{array}$ \\
\hline $\begin{array}{l}\text { Electron } \\
\text { microscope }\end{array}$ & $\begin{array}{l}\text { Processes interweave and } \\
\text { occasionally surround } \\
\text { aggregates of intercellular } \\
\text { collagen. Cells are } \\
\text { surrounded by often } \\
\text { duplicated basal lamina. }\end{array}$ \\
\hline
\end{tabular}

On the basis of clinical presentation and radiographic findings, a differential diagnosis of benign lesion was considered. Differentiation of this lesion required further analysis via histology and immunehistochemistry. The patient underwent complete surgical excision of the tumor at L3 and found mass of size $2.1 \times 1.0 \times 1.5 \mathrm{~cm}$ soft capsulated gray red mass. The pathological report confirmed a diagnosis of Neurilemoma.

Table3: Immunohistology chemistry (IHC) of Neurilemoma.

\begin{tabular}{|l|l|}
\hline IHC Marker & Neurilemoma \\
\hline GFAP & Variable-, rarely+ \\
\hline S-100 Protein & +++++ \\
\hline VIM & $+++/-$ \\
\hline CD 57 & + \\
\hline CK-P & $-+/-$ \\
\hline SMA & $-+/-$ \\
\hline $\begin{array}{l}\text { Ki-67 Labeling } \\
\text { index }\end{array}$ & Variable \\
\hline Desmin & + - Figure 1: \\
\hline
\end{tabular}

\section{Discussion}

Neurilemoma is a benign few truly encapsulated nerve sheath tumor composed of schwannoma cells which normally produce the insulating myelin sheath covering peripheral nerves, also known as Schwannoma/neurinoma and Schwann cell tumor. The pick incidence is in the $3^{\text {rd }}$ to 6 th decades of life. It affects males and females equally $\&$ often occurs in flexor surface of 

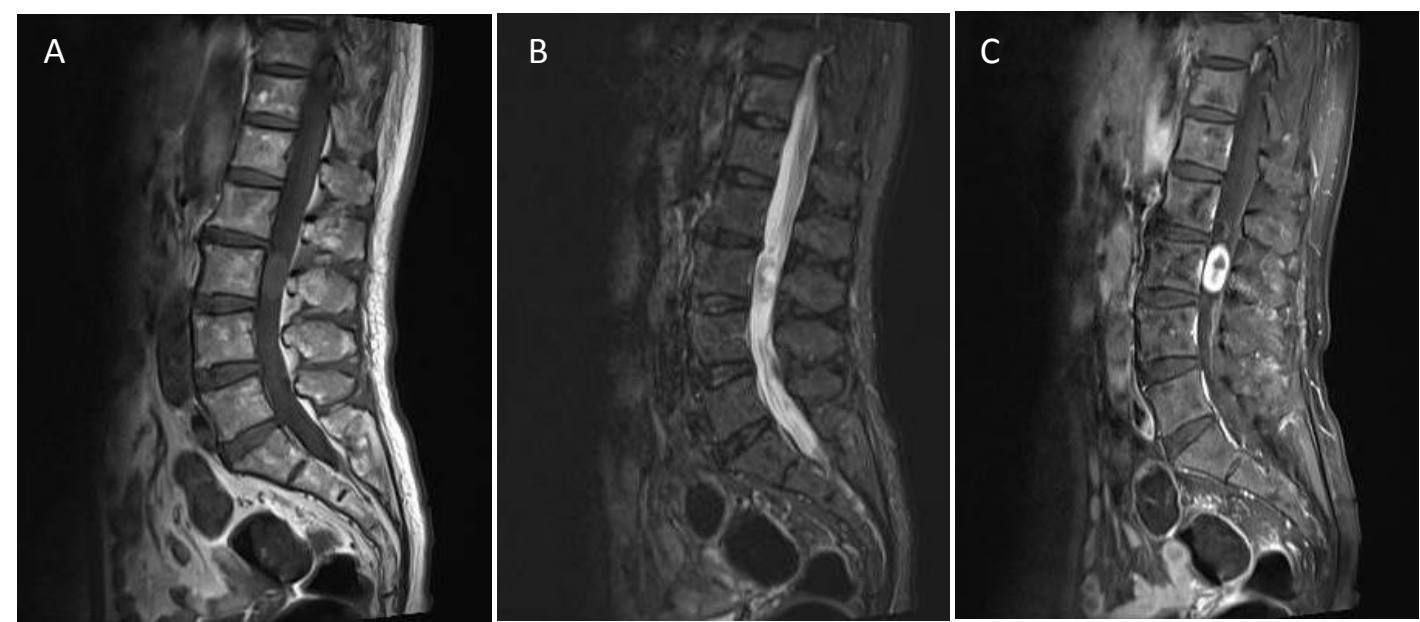

Fig 1: (a) a 61 yrs female with Neurilemoma, A sagital T1 weighted with TE. TR 9.6/650 with 3.0 $\mathrm{T}$ unit (siemen) MRI image shows isointensity oval shaped with clear margin mass at level of L3, (b): T2 weighted sagital images with TE/TR 52/4000 shows slightly high signal in central and low signal in periphery (c): T1WI sagital with contrast GdDTPA shows hyperintense in periphery and Hypointense in central.

extremities and head, neck, thorax and lumber. More than half of these lesions are extramedullary intradural, about $25 \%$ are completely extradural, some $15 \%$ are both intra and extradural, and very rarely are seen intramedullary. ${ }^{3}$ Often associated with mutations affecting NF1 and NF2 gene. ${ }^{4}$ They are universally strongly $\mathrm{S}-100$ positive. Patient may have positive Tinel's sign in the distribution of the nerve. Its malignant transformation is extremely rare. These tumors are less frequently seen in children. Tumors in the cauda equina often reach a considerable size without painful symptoms, due to the mobility of the roots and the wide intradural space. ${ }^{5}$ Neurilemoma are usually asymptomatic or few symptoms are present.

We have reviewed some journal and found that majority of Neurilemoma are encapsulated, solid, smooth, cyst or mixed with a pattern of different structures identified as Atoni A and Atoni B. ${ }^{6}$ The A areas express a solid hypercellularity and impaled Nuclei known as Verocay texture. The $\mathrm{B}$ areas are hypocellular with lax histological texture. Histopathological features include spindles cells arranged in intersecting bundles of atoni $\mathrm{A}$ and with loosely arranged cells of atoni $\mathrm{B}$, long club shaped nuclei, dense chromatin, cytoplasm cell borders are obscured as in Table 2. By IHC confirm diagnosis through S-100 protein strongly ${ }^{(+++)}$, VIM ${ }^{(++)}$, desmin ${ }^{(+-)}$, $\mathrm{Ki} 67$ labeling is high and Vimentum positive ${ }^{[1]}$ as shown in Table 3 .

Magnetic resonance imaging (MRI) is the primary imaging modality used for the assessment of both intracranial and spinal tumor. Although computed tomography (CT) provides better demonstration of small or subtle calcifications within tumors, MRI provides superior delineation of the extent of tumor due to its greater soft tissue contrast, multiplanar imaging capability, and ability to obtain complementary information with T1and T2-weighted sequences. ${ }^{7} \quad$ The importance of early diagnosis and treatment of cauda equina tumor is widely recognized (Fearnside and Adams 1987). ${ }^{8}$ 


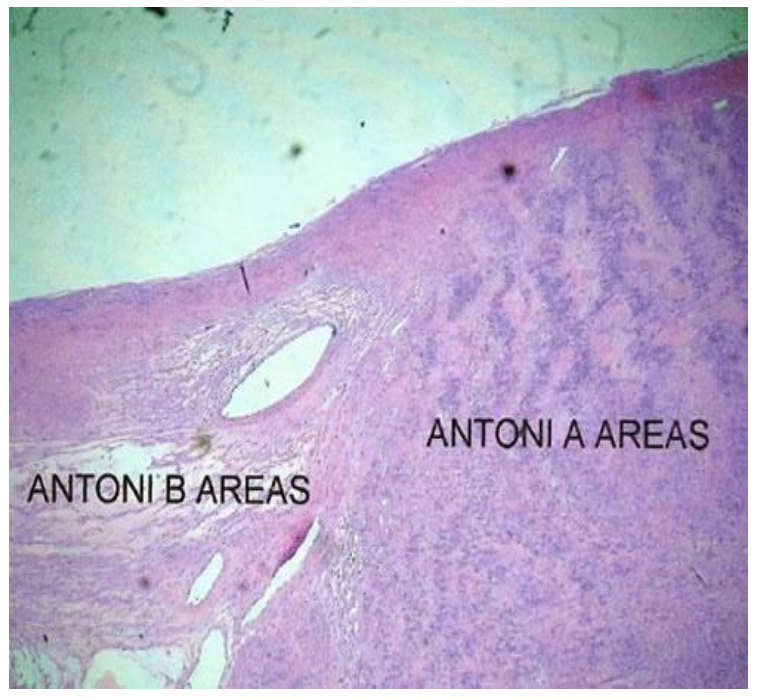

Fig 2: (a) Hematoxylin and eosin stains with magnification 400x demonstrate an Atoni A and An Atoni B which is typical feature of Neurilemoma.

Differential diagnosis of Neurilemoma includes Ependymoma. MRI of Neurilemoma at cauda equina signal characteristics: Neurilemomas show isointensity on $\mathrm{T} 1 \mathrm{Wi}$ and have typical marked hyperintensity on T2Wi. Sometimes a target appearance with centrally less high signal are noted as shown in Table 1.

Enhancement is variable and can be intense and homogeneous in some lesion, while others may only show faint peripheral enhancement. ${ }^{3}$ Where as in Majority of Ependymoma on unenhanced T1 weighted MRI shows isointensity-or slightly low signal, and slightly High signal on T2 weighted MRI. After Gd-PDTA injection, tumor is heterogeneously enhanced and shows hyperintense in periphery and hypointense in central as in Figure 1(c). However most of Ependymoma enhanced homogeneously with clear margin. ${ }^{9}$ Erosive changes are seen commonly in ependymomas, most likely because they are slowly growing. Osseous erosion and thinning of the pedicles and lamina are far more common in the ependymoma of the lower spinal canal and filum. ${ }^{10}$

\section{Conclusion}

The diagnosis of spinal tumors, mainly Neurilemoma is really confusing. Morphology can be misleading hence immunohistochemistry and/or ultrastructural study is necessary for correct diagnosis. ${ }^{11}$ Neurilemomas are more common, histopathologically Neurilemoma has typical Atoni A and Atoni B pattern. ${ }^{10}$ By IHC S100 protein is strongly positive in Neurilemoma. By MRI Neurilemoma mostly shows isointense in T1WI weighted images and hyperintense in T2WI, with contrast Neurilemoma shows heterogeneous enhancement. Though this tumors must be included in the differential diagnosis of intradural mass of the cauda equina region including ependymoma, neurinoma, hemangioblastoma, meningioma, lipoma, epidermoid, metastasis, and rarely paraganglioma. $^{12}$ Most Authors consider total removal of the tumor can have a positive influence on the prognosis. ${ }^{13}$ But Nerve sheath tumor (Neurilemoma) should excise incompletely because complete removal can cause damage of many nerve roots. In spite of the incomplete removal of the tumors, the risk of recurrence is low.

\section{References}

1. Merayo-Chalico CE, Santana-Ríos Z, Gómez-López JM, Martínez-Ríos C et.al. A Neurilemoma (NLM) or giant retroperitoneal Schwannoma . Rev Mex Urol 2009;69(1):28-31. 
2. Rosai \& Ackerman's, Surgical pathology text book, volume-2, $10^{\text {th }}$ edition. J. Rosai, 2011.

3. Van Goethem JWM, Hauwe LVD, Özsarlak Ö,et.al. Spinal tumors, European Journal of Radiology 50 (2004).

4. Riffaud L, Morandi X, Massengo S, Carsin-Nicol B, et.al. MRI of intramedullary spinal schwannomas: case report and review of the literature. A case report. Neuroradiology (2000) 42:275279.

5. Kagaya, Abe, Eiji, Sato, Kozo, Shimada, et.al. Giant Cauda Equina Schwannoma: A Case Report, Spine: 15 January 2000 Volume 25 - Issue 2 - p 268.

6. Ysoo L, Kim JO, Park SE. Ancient schwannoma of the thigh mimicking a malignant tumour: a report of two cases, with emphasis on MRI findings The British Journal of Radiology, 83 (2010), e154-e157.

7. Yuh EH, Barkovich AJ, Gupta N. Imaging of ependymomas: MRI and CT. Childs Nerv Syst (2009) 25:1203-1213.

8. Yoichi S, Naohisa M, Yujikasukawa, $\mathrm{MH}$. Clinical features of cauda Equina Tumors Requiring Surgical Treatment, Tohoku j. Exp. Med, 2006, 209, 1-6.

9. Bo S, MD, Chungcheng W, MD, James W, MD, Ali L, MD. MRI Features of Intramedullary Spinal Cord Ependymomas. J Neuroimaging 2003; 13: 346-351.
10. Heather K, Evelyn ML, Sklar M. Judith DP, Jocelyn H. MR Characteristics of Histopathologic Subtypes of Spinal Ependymoma. AJNR Am J Neuroradiol 1996;17:143-150.

11. Kauda E, Yerlesmis. Cauda Equina Paraganglioma with Ependymoma-Like Histology: A Case Report. Turkish Neurosurgery 2012, Vol: 22, No: 3, 353359.

12. Miroslav H, Roberto S, Pozzi-M, Miran S. Paraganglioma of the Cauda Equina: A case report and review of the MRI features. Acta Univ. Palacki. Olomuc., Fac. Med., January 12, 1998.

13. Celli P, Cervoni L, Cantore G., Department of Neurological Science, Ependymoma of the Filum Terminale: Treatment and prognostic factors in a series of 28 cases Neurosurgery, university of Rome, Rome, Italy. Acta Neurchir (wien) (1993) 124:99-1. 